doi: 10.32620/oikit.2019.83.10

УДК 629.735.33

Н. С. Топал, В. М. Андрющенко

\title{
Пошкодження від щілинної корозії в конструкціях літаків та їх виявлення
}

\author{
Національний аерокосмічний університет ім. М. Є. Жуковського \\ "Харківський авіаційний інститут»
}

\begin{abstract}
Представлені приклади руйнування конструкцій літаків внаслідок корозії металів в умовах втомного навантаження. Показано, що щілинна корозія, яка являє собою посилення корозії в щілинах і зазорах між двома металами, а також в місцях нещільного контакту металу з неметалевим корозійноінертним матеріалом призводить, в з'єднаннях обшивок з підкріплюючим силовим набором, до появи продуктів корозії, які можуть привести до вспучування одних елементів з'єднання відносно інших елементів і провокувати відрив закладних головок заклепок з подальшим розвитком втомних тріщин і руйнуванням конструкцій літака.

Показано, що візуальний огляд не завжди ефективний для виявлення корозійних пошкоджень, а іноді неможливий, наприклад в замкнутих внутрішніх об'ємах конструкцій. Приведені нові розробки в області датчиків та обладнання для виявлення корозійно активних речовин і корозійних пошкоджень. Серед них надана інформація про датчик (органіко-керамічний композит), що містить провідний комплекс. Коли композит піддають впливу водних рідин, його провідність втрачається. Коли композит висохне, датчик досягає своїх початкових значень опору.

Приведена інформація про оптичний датчик для виявлення корозії в планерах. Цей датчик заснований на дистанційному виявленні іонів алюмінію, що утворюються в процесі корозії.

Представлена розробка багатопараметричного інтегрованого датчика для оцінки структурної цілісності алюмінієвих сплавів, регіструючого концентрацію хлорид-іонів, виділення водню, зміну вологості та деградацію матеріалу.

Наведена інформація про оптичні датчики, засновані на випромінюванні флуоресценції, які використовують для виявлення специфічних іонів, таких як алюміній, що вказує на початок корозії алюмінієвого сплаву.

Надана інформація про розробку покращених цифрових рентгенівських методів для виявлення корозії в конструкції літаків.

Зроблено висновок про необхідність поєднання візуального контролю і контролю 3 використанням засобів і методів виявлення корозійно активних речовин й корозійних пошкоджень.
\end{abstract}

Ключові слова: корозія металів, щілинна корозія, корозійно-втомні пошкодження, методи виявлення корозії, датчик корозії

28 квітня 1988 року літак Boeing 737, термін експлуатації якого складав 19 років, що працював у авіакомпанії Aloha, у польоті на висоті 2400 футів зазнав втрату великої частини верхньої обшивки фрюзеляжу (рис. 1, 2) [1, 2].

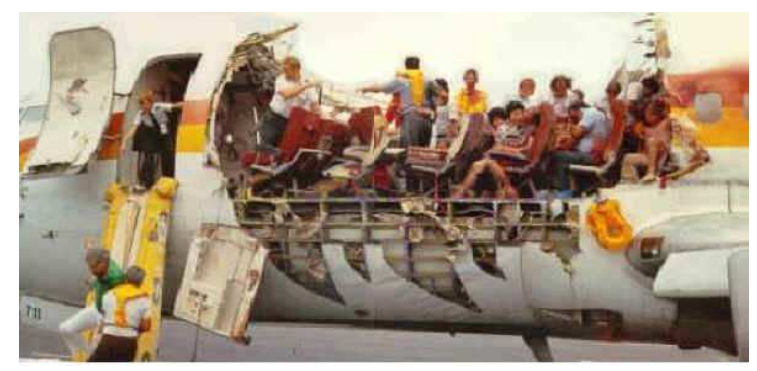

Рис. 1. Вид зруйнованого літака Boeing 737 внаслідок корозійних і втомних пошкоджень 
Дивом пілот зумів приземлити літак на острові Мауї, Гаваї.

При розслідуванні цієї події були виявлені втомні тріщини також і в інших місцях конструкції літака, зокрема в обшивках в зоні їх послаблення отворами під заклепки крайніх рядів [2].

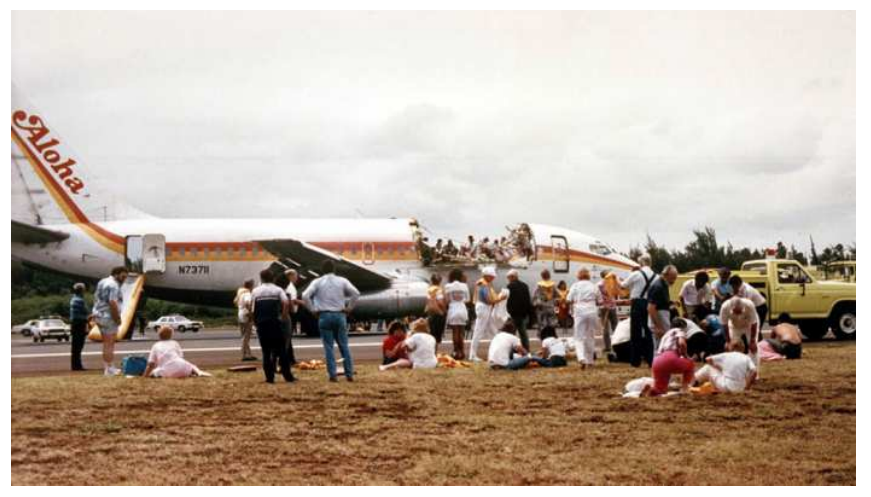

Рис. 2. Зовнішній вигляд літака

Boeing 737 авіакомпанії Aloha після приземлення в аеропорту Мауї [3]

У звіті про розслідування Національного комітету з безпеки перевезень, виданого в 1989 році, інцидент пояснювався прискореною корозією втомою панелей фююзеляжу та недоробкою технічного персоналу, якій в процесі технічного обслуговування не зміг вчасно виявити пошкодження від корозії та втоми, які й призвели до інциденту (поздовжні з'єднання внахлест з'єднують великі панелі і проходять уздовж фюзеляжу. Не передбачалося, що втомні тріщини можуть бути проблемою, яка призведе до катастрофічних наслідків).

Огляд інших аналогічних літаків показав і у них проблеми з корозією i втомними ушкодженнями в з'єднаннях конструкцій.

Поява між обшивкою и силовим набором в з'єднаннях збірних панелей об'ємних продуктів корозії внаслідок дії щілинної корозії приводить до спучування обшивки проміж елементами кріплення. Таким чином закладні головки заклепок виглядають нібито утопленими (рис. 3)

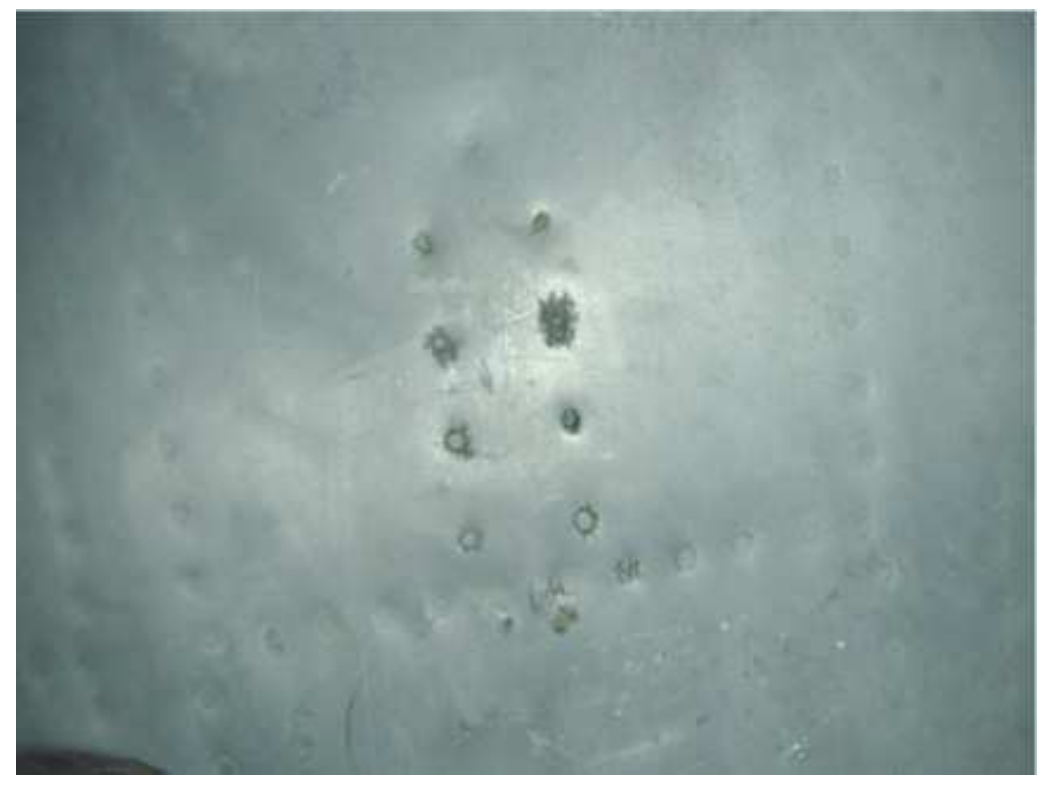

Рис. 3. Вид на нижню поверхню фюзеляжу літака Boeing 737, з якого видно, що побічний продукт корозії розширився і підпирає зсередини обшивку таким чином, що закладні головки заклепок здаються затопленими [4] 
Просунута фрорма щілинної корозії дає велику кількість продуктів корозії, які роз'єднують з'єднані між собою елементи конструкції, видавлюючи обшивку і відриваючи ії від елементів силового набору і елементів кріплення. Головки заклепок виявляються нижчими, ніж навколишня поверхня обшивки. Під час розслідування інциденту літака Aloha Boeing 737 [5] було знайдено докази таких пошкоджень (рис. 4) [6]. Схема продольного з'єднання обшивок фрюзеляжу та його перетину по осі заклепок крайного ряду показані на рисунках 5 та 6 відповідно.

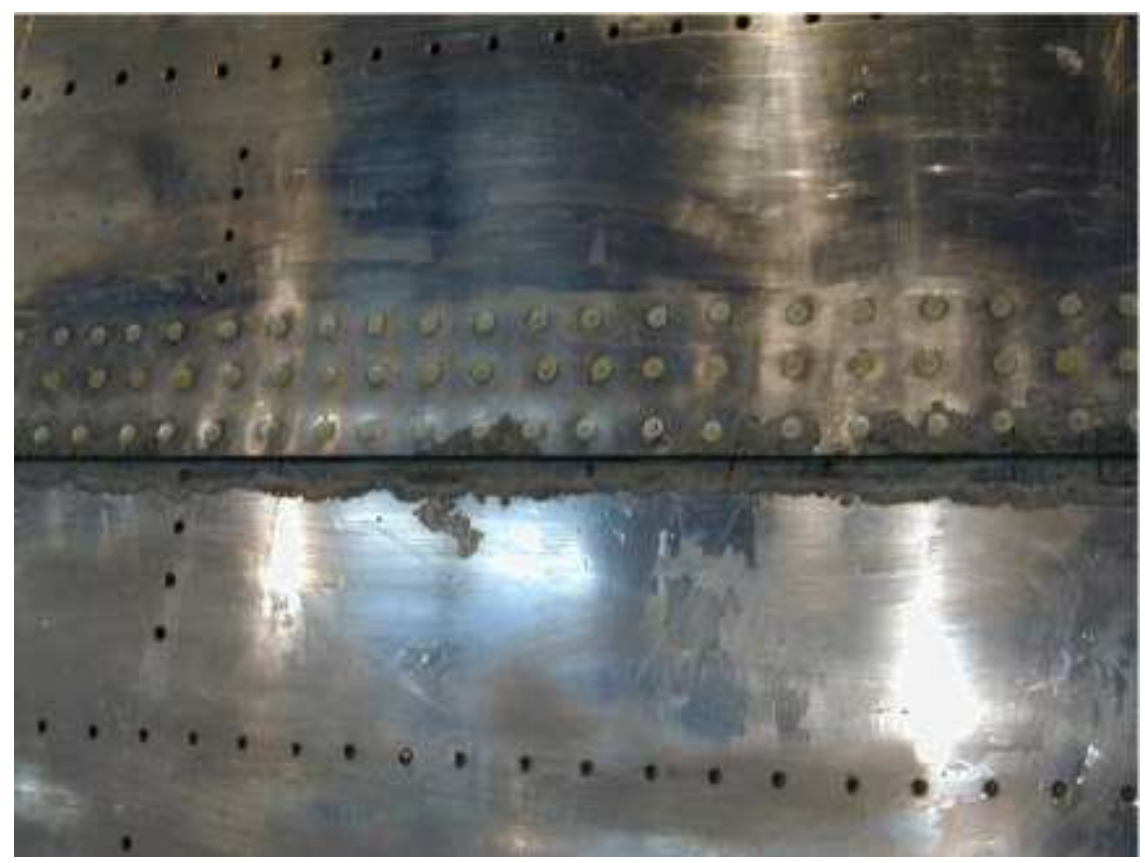

Рис. 4. Вигляд зовнішньої поверхні літака Boeing 737 при наявності продуктів корозії між обшивками, що з'єднані внахлест

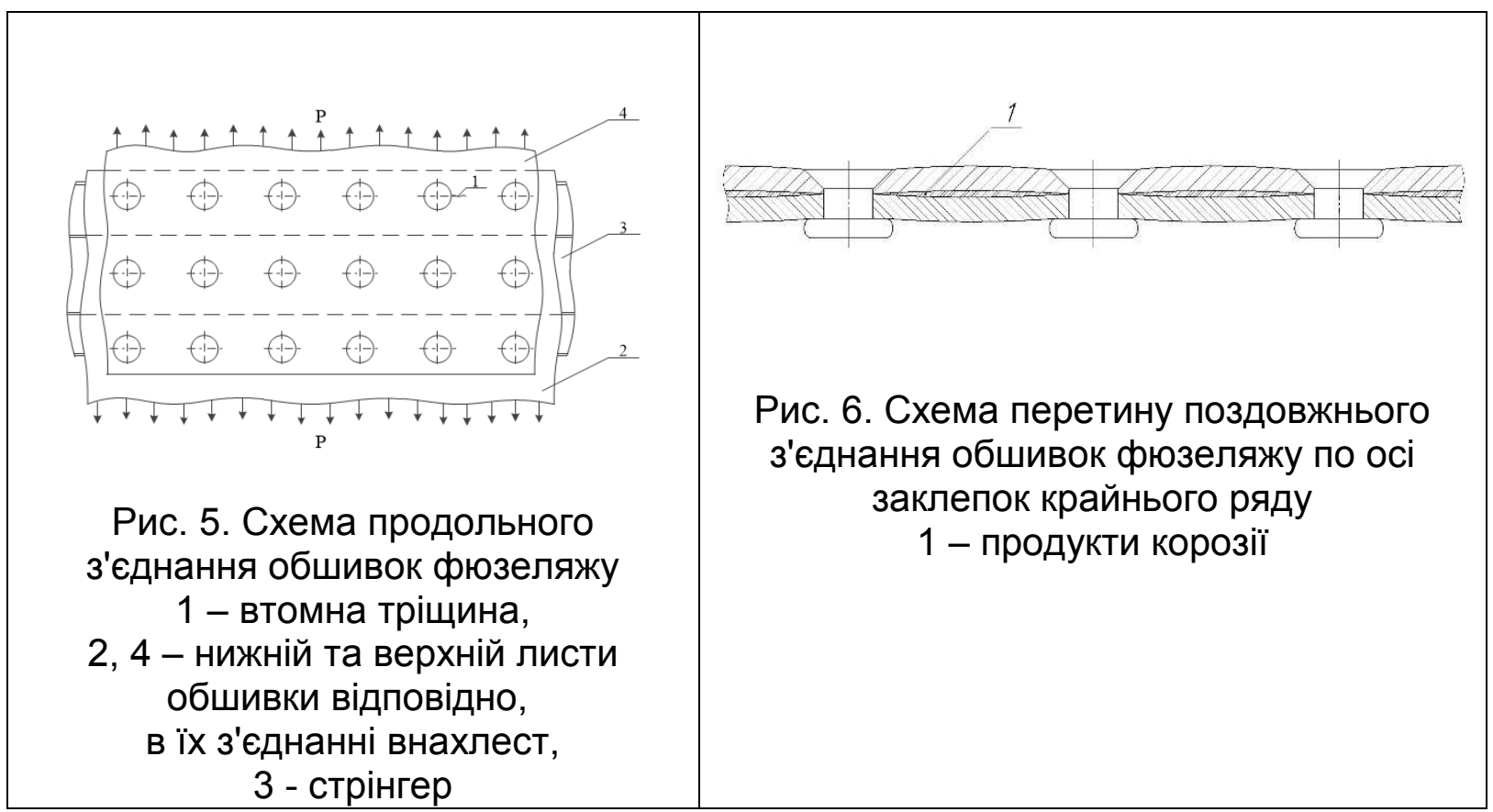


Нищівна дія корозії особливо наявно проявляється для літаків, які працюють в умовах дії випарів морської води. В якості прикладу можна розглянути корозійне пошкодження морського патрульного літака Lockheed CP140 Aurora (рис. 7).

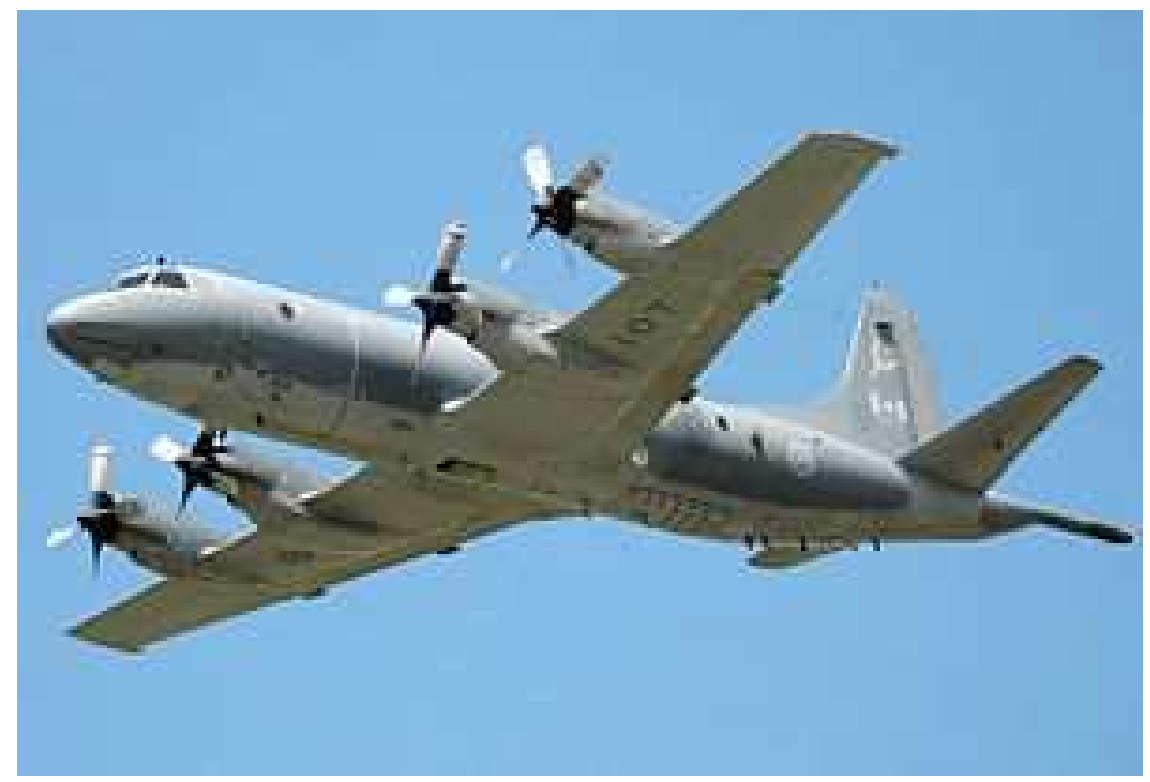

Рис. 7. Загальний вигляд літака Lockheed CP-140 Aurora [7]

В панелях на зовнішній частині фрюзеляжу морського патрульного літака були виявлені ушкодження. Огляд виявив щілинну корозію в панелях (рис. 8, 9) [8], які виходили на зовнішню поверхню літака.

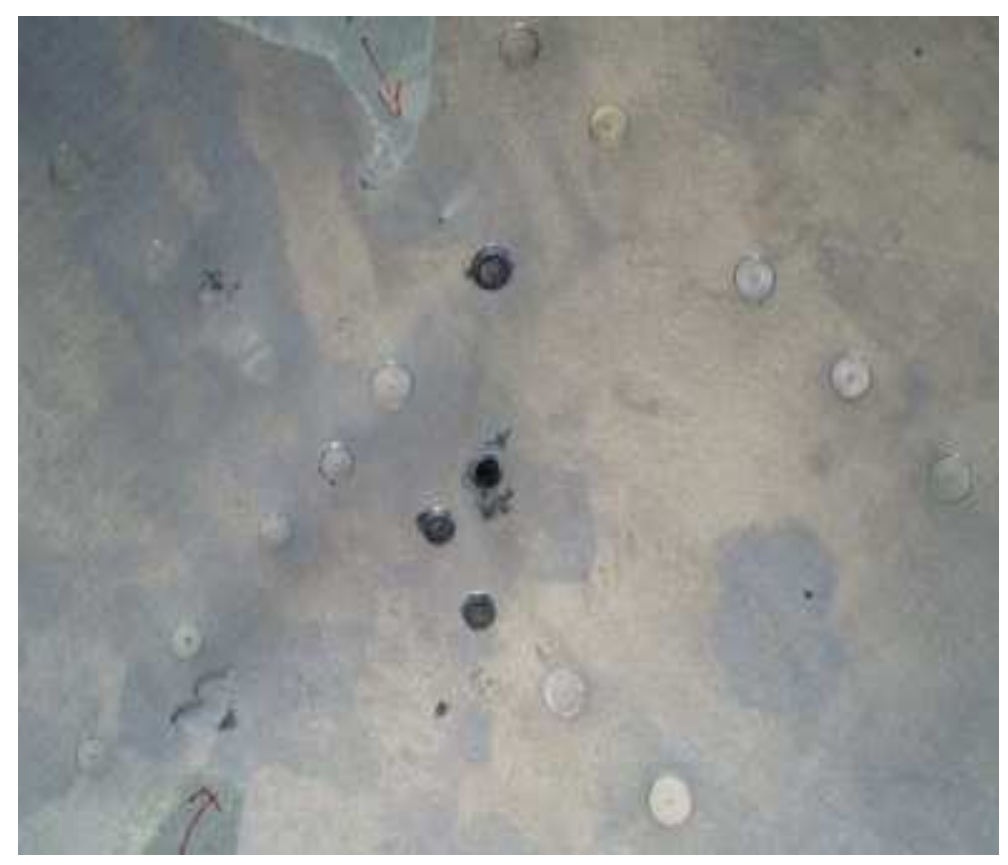

Рис. 8. Вид ззовні на панель, ушкоджену щілинною корозією 
Добре видно, що обшивка спучилася (внаслідок появи і постійного збільшення продуктів корозії між обшивкою и ії̈ підкріплюючим силовим набором), наслідок чого закладні головки заклепок виглядають утопленими, а декілька закладних головок відірвалися.

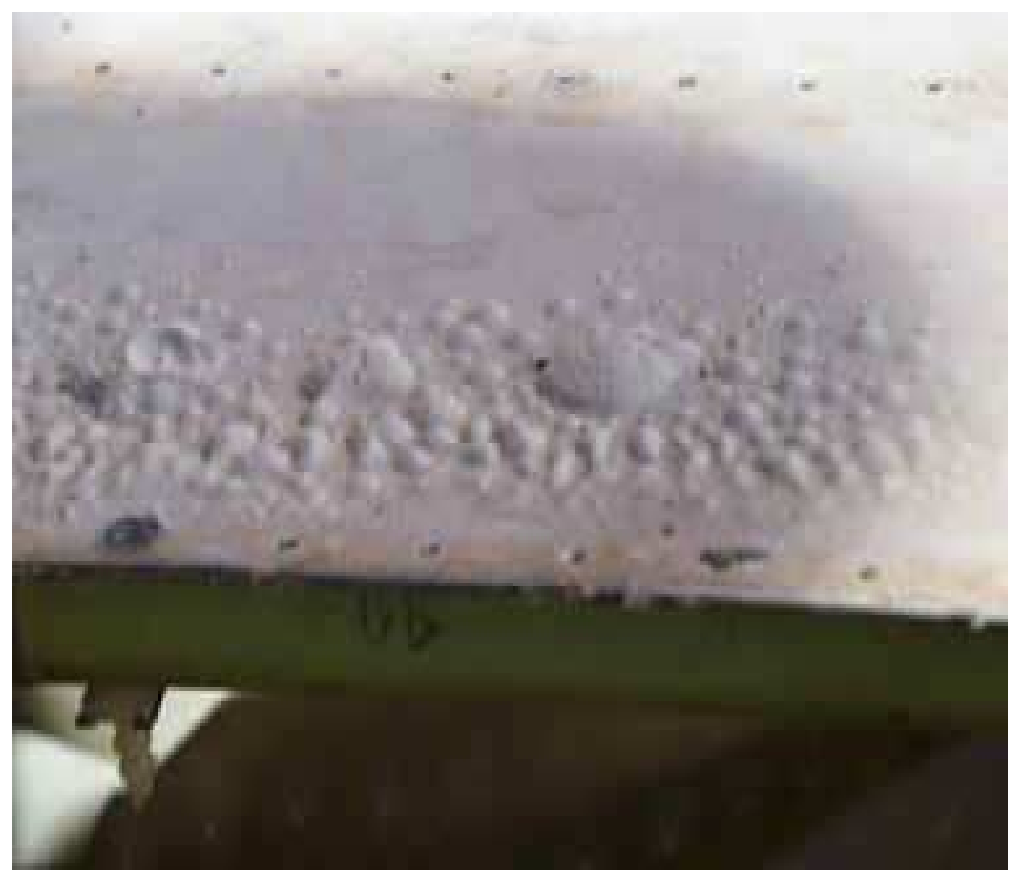

Рис. 9. Вид на фююзеляж, що показує пошкодження захисного покриття внаслідок розвитку під ним корозії

Приклад корозії на поверхні панелі літака приведений на рис. 10 та 11 [9].

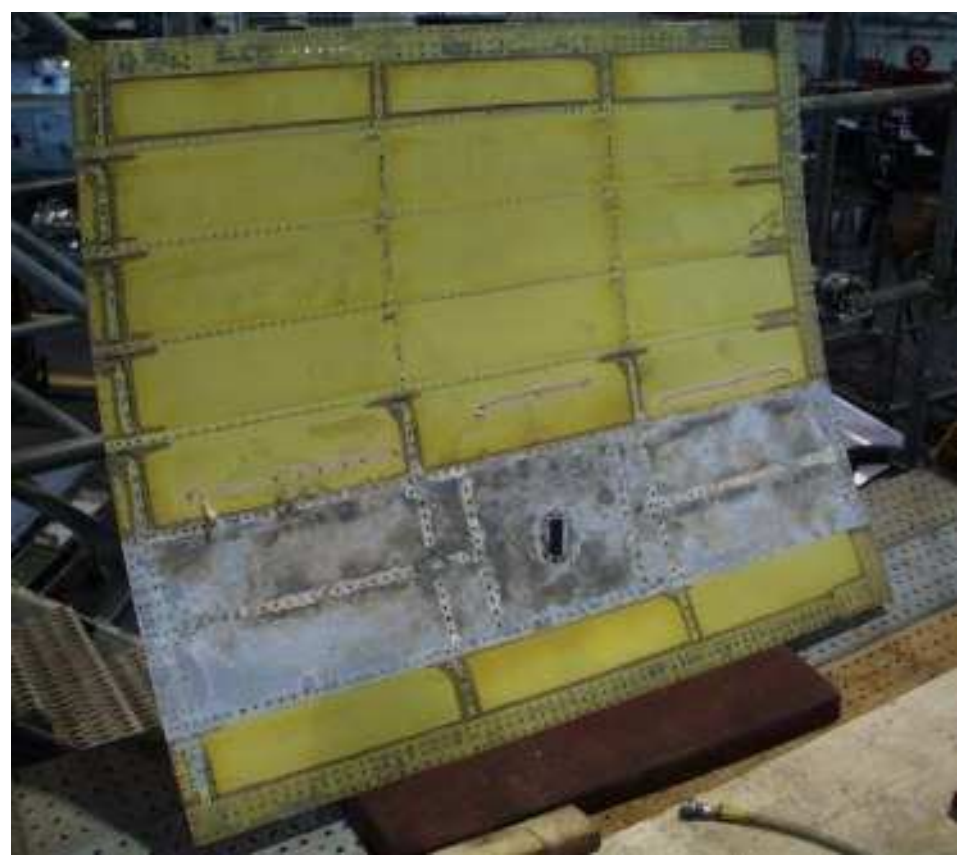

Рис. 10. Вид на панель, в нижній частині якої виявлена сильна корозія 


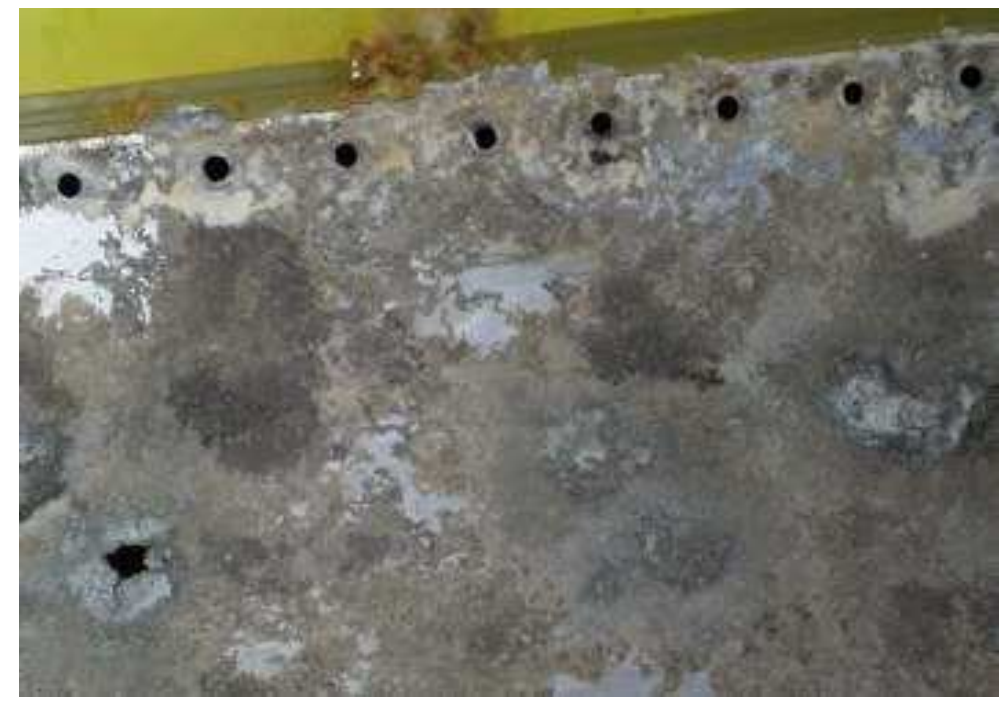

Рис. 11. Фотографрія крупного плану, яка демонструє ступінь корозії

Корозія металів, руйнування металів внаслідок хімічної або електрохімічної взаємодії їх з корозійним середовищем - це те, що вимагає виявлення, лікування і, по можливості, запобігання.

Існує багато форм корозії літаків. Найбільш відомий випадок, коли алюміній взаємодіє з водою, створюючи оксид алюмінію [10]. Оксид алюмінію не має міцністі та властивостей алюмінію. Алюміній, який був запозичений 3 конструкції для створення оксиду алюмінію, виключаєтся з конструктивносилової схеми літального апарата и не забезпечує сприймання навантажень, під які він був призначений. Ця частина навантаження додатково завантажує матеріал, який залишився в працюючий конструкції. Збільшення навантаження може привести до значного зменшення втомної довговічності конструкції. Ось чому необхідне якомога найбільш раннє виявлення наявності початку розвитку корозійних процесів, забезпечення контролю за їх розвитком і, де це необхідно, ремонт або заміна надмірно окислених деталей.

Як правило, корозія виявляється візуально [10]. Під час технічного обслуговування, коли техніки йдуть перевіряючи кожен доступний дюйм планера літака, або коли літальний апарат очищають до чистого металу в період підготовки до перефарбування.

Перевірки проводяться скрізь, де може просочуватися вода, куди можуть попасти сіль і кислоти. Повинні перевірятись підлога камбузів, туалети, нижня проверхня фрюзеляжу літака, закриті місця внутрішньої поверхні крила, а також елементи конструкції, які формують внутрішні порожнини всередині елеронів, закрилків і т. п.

На жаль, іноді найбільш сумлінні візуальні перевірки дають недостатньо добрі результати. Це вочевидь витікає з досвіду власника літака «Cessna 182» у Флориді Скотта Нельсона, який виявив жахливу корозію, заховану всередині «Cessna 182», яку він 3 любов'ю підтримував роками. Реальний стан пошкоджень корозією проявився тільки після падіння на цей літак ангару під час урагану "Вілма". Після того, як літак був визволений з-під уламків і розібраний для реставрації, виявилось що це не найбезпечніший, найбільш впорядкований 182, як гадали його власники. «Насправді ми володіли літаком 
з найстрашнішою корозією, яку я коли-небудь бачив" писав Нельсон у випуску журналу Cessna Owner у квітні 2007 року [10].

Таким чином візуальний контроль далеко не завжди дає об'єктивну інформацію про стан корозійного пошкодження літака, особливо в його малодоступних зонах.

В такому разі у пригоді можуть стати датчики і обладнання для виявлення корозії.

Для виявлення рідини в обмежених конструкціях повітряних суден в Бельгії, в Левенському католицькому університеті на кафедрі металургії та матеріалознавства розроблений датчик (органіко-керамічний композит), що містить провідний комплекс.

Коли композит піддають впливу водних рідин, провідність по суті втрачається при адсорбції і набуханні матеріалу матриці. Робота розробленого датчика базується на даному ефекті [11].

У літаку водні рідини, що виникають в результаті витікання, конденсації або попадають в середину конструкцій, наприклад внаслідок опадів, можуть призвести до виникнення корозії частин конструкції. Ця небезпека стосується і так званих підлогових конструкцій в пасажирській кабіні. Надійний датчик для виявлення водяних рідин, який регулярно опитується, може значно допомогти скоротити витрати (в разі вчасного усунення виявленої небезпеки) на ремонт і технічне обслуговування.

Датчик розроблявся з метою забезпечення умов його роботи при наявності обмеженого простору, наприклад у замкненому просторі балки підлоги літака [11].

Для досягнення цієї мети розроблений датчик, якій має в діаметрі всього 1 мм (рис. 12, 13). Датчик на рисунку 12 обведений колом.

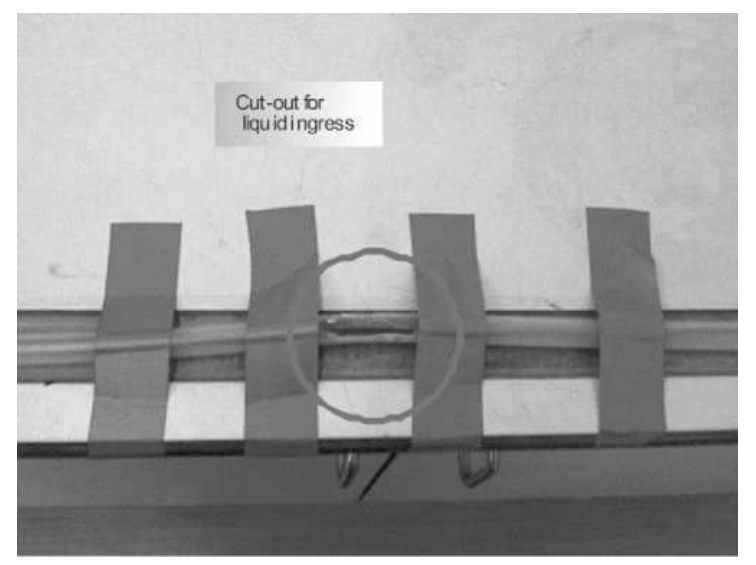

Рис. 12. Установка для дослідження проникнення водних рідин у замкнутий простір, наприклад, конструкція балки перекриття. Датчик в трубці має діаметр 1 мм

Рис. 13. Простір між панелями підлоги в камбузній зоні літака Boeing 737 з встановленим датчиком, якій має діаметр 1 мм

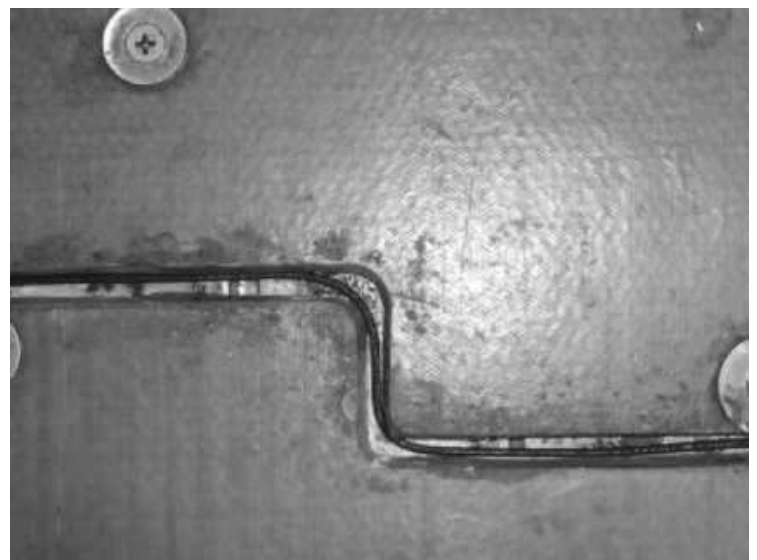


Збільшений вигляд частини датчика i його типовий переріз показаний на рис.14.
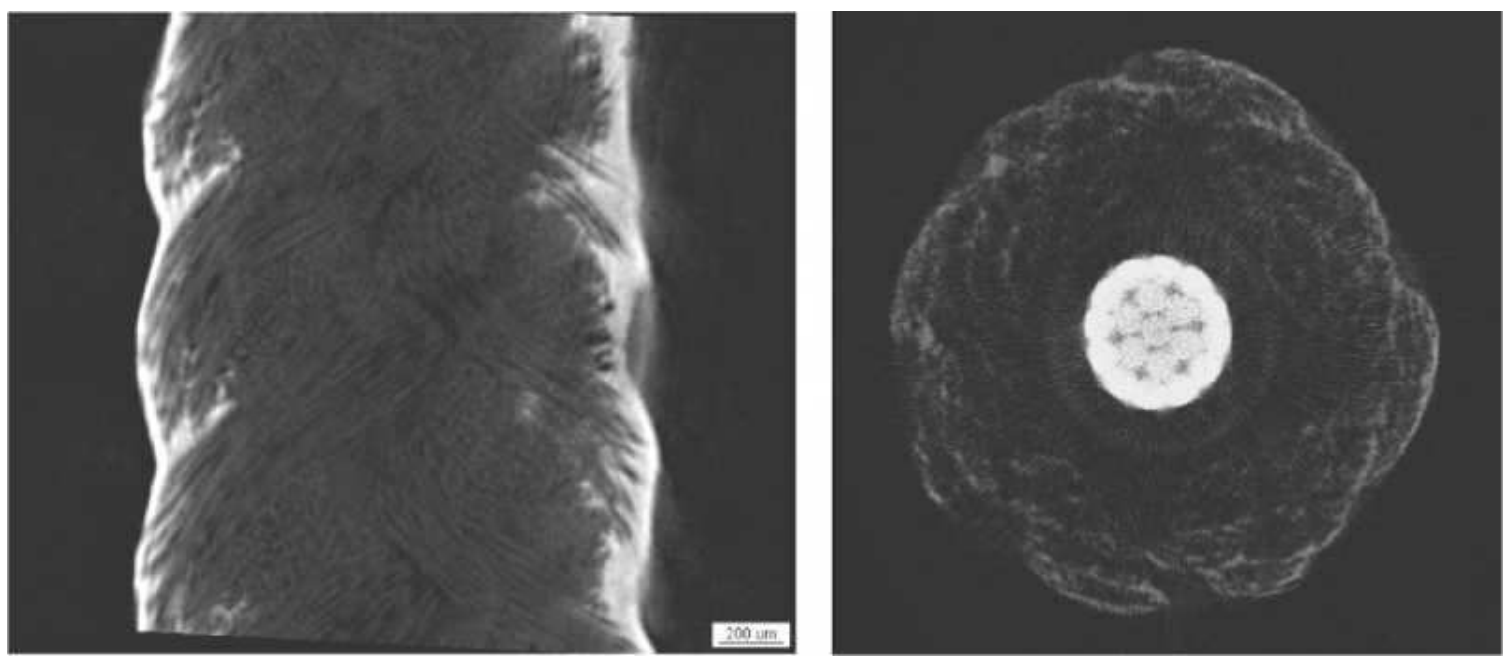

Рис. 14. Типові зовнішній вигляд і мікро-переріз датчика. Поліамідний шнур просочений композитом TiCN / PVA (світло-сіра прокладка на зовнішній стороні датчика на лівому і правому знімку). Поліамідний шнур містить електричний провід (світло-сірий циліндр в центрі правої частини рисунка)

В умовах реального літака після проникнення в конструкцію води і зволоження датчика процес переважно $є$ оборотним, тобто композит датчика висохне, і датчик знову поступово досягає своїх початкових значень опору. Однак простір між панелями підлоги дуже обмежений, i тому процес висушування проходить не швидко. Якщо швидке сушіння було б можливим, то елементи конструкції підлоги, ймовірно, зовсім би не вражались корозією.

Процес повільного сушіння $€$ великою перевагою для даної конструкції датчика, оскільки немає необхідності в постійному записі даних.

Розроблені датчики сертифікували і використали в діючому авіалайнері (Boeing 737-500 компанії Lufthansa) сумарно впродовж близько 100 годин польоту.

Варто відзначити, що хоча датчик був оптимізований для конструкцій підлоги в літаку, існує багато інших можливостей застосування через надзвичайно низькі витрати на його виробництво і просту процедуру вимірювання та інтерпретації даних. Крім того, за допомогою модифікації матеріалу матриці концепція датчика може бути поширена на інші неводні рідини, наприклад, гідравлічні рідини [11].

Так як літаки регулярно працюють в різних атмосферних умовах, вони 3 часом впливають на їх структурну цілісність [12]. Незважаючи на схеми захисту та відбору матеріалу, періодичний вплив хлоридів, забруднення, температурні градієнти та волога забезпечують необхідні електрохімічні умови для розвитку та великої кількості корозії в конструкціях літаків [12].

У роботі [12] частково представлена розробка багатопараметричного інтегрованого датчика корозії XCorr (рис. 15). Він складається з вуглецевих нанотрубок/поліанілінових полімерних чутливих елементів і комерційно- 
стандартного датчика. Він розроблявся в першу чергу з метою забезпечення засобів для більш точної оцінки структурної цілісності алюмінієвих сплавів. Отримані результати експериментальних випробувань на концентрацію хлорид-іонів, виділення водню, зміни вологості та деградацію матеріалу.

Цей датчик $є 16$-елементним пасивним електрохімічним датчиком, який не вимагає будь-якої прикладеної напруги для роботи (рис. 15 (а)). 16 елементів датчика призначені для вимірювання рівномірної або локалізованої корозії через природний корозійний струм між анодними і катодними ділянками на поверхні металу, коли він піддається впливу корозійного розчину. 16 елементів зонда з'єднані разом через загальний інтерфейс в електроніці (рис. 15 (b)). Корозійний водний розчин створює як катодну, так і анодну ділянки на елементах на головці зонда (рис. 15 (с)). У зв'язку з цим, корозія на анодних ділянках може розвиватися як на реальній поверхні металу. Система об'єднує дані з 16 окремих елементів і екстраполює як середні, так і максимальні річні швидкості корозії.

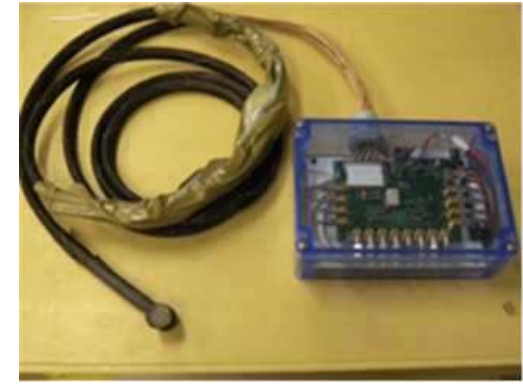

a

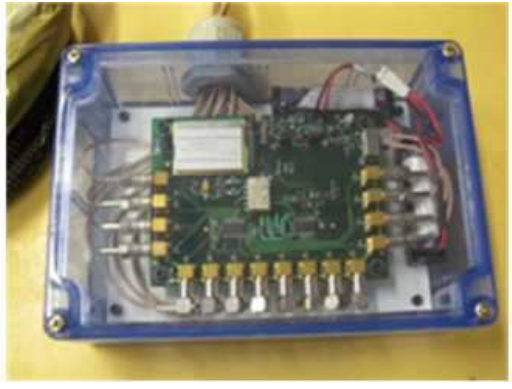

b

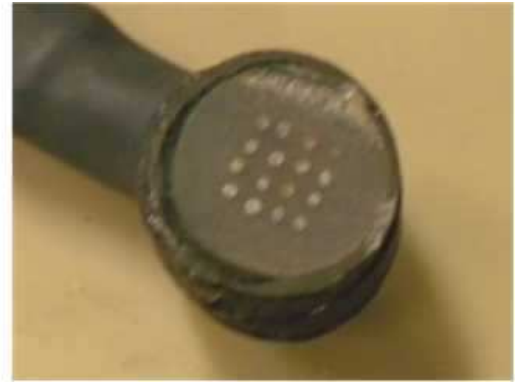

C

Рис. 15. (a) багатоканальний датчик XCorr; (b) електронний блок датчика; (c) крупний план 16-елементного зонда

В роботі [13] приведена інформація про оптичні датчики для виявлення корозії в планерах.

Використання датчиків для виявлення корозії алюмінію в конструкціях планера може дозволити значно скоротити витрати на їх технічне обслуговування. Відповідний датчик може виявляти корозію на ранній стадії, коли видалення корозійного матеріалу з вихідної структури не передбачає структурного ремонту. Крім того, гарантуючи, що корозія виявляється локально ефективним датчиком, необхідність перевірок в деяких районах може бути усунена або, принаймні, інтервали перевірки можуть бути збільшені, зі значним скороченням витрат, але зберігаючи консервативний підхід до безпеки літаків.

У даній роботі представлений оптичний датчик (рис. 16), який може бути використаний для виявлення продуктів корозії всередині критичних з'єднань літаків, які, як відомо, дуже схильні до корозії. Цей датчик заснований на дистанційному виявленні іонів алюмінію, що утворюються в процесі корозії. Обговорений спосіб підготовки цих датчиків та приведені отримані результати. 


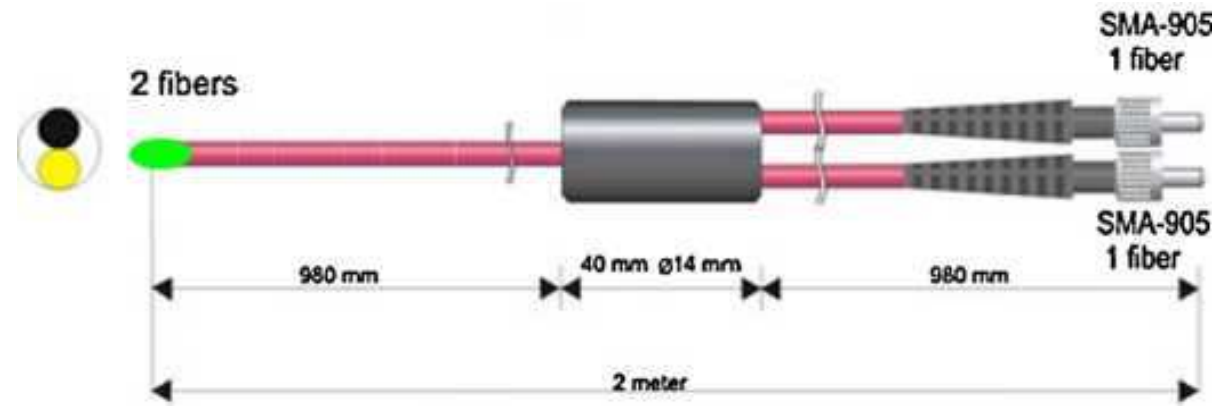

Рис. 16. Оптичний датчик з мульти-розгалуженим пучком волокна (кремнеземне волокно)

Оптичні датчики, засновані на випромінюванні флуоресценції, можуть бути використані при виявленні специфічних іонів, таких як алюміній, що вказує на початок корозії алюмінієвого сплаву. Технологія волоконної оптики $\epsilon$ адекватною для виробництва датчиків, які можуть бути розміщені в закритих областях в літаку. Їх невеликий розмір і гнучкість $€$ необхідними для цього застосування.

8-гидроксихинолин (8НQ) вважали кращим фрлуорофором для детектування алюмінію. За даними тестів, проведених за допомогою даного датчика, він демонструє достатню чутливість до іонів алюмінію і на їх виявлення не сильно впливає наявністю інших іонів, таких як $\mathrm{Ca} 2+, \mathrm{Na}+$, $\mathrm{Mg} 2$ + i Cu2 +. Необхідні подальші дослідження для оцінки специфічного впливу кожного з цих іонів на поведінку флуоресценції $\mathrm{Al} 3+$ у вибраній довжині хвилі. Наступний крок цього дослідження передбачає використання польових випробувань для оптимізації налаштування датчиків, визначення граничних параметрів, таких як максимальна довжина оптичного волокна для належного виявлення флуоресценції, а також оцінка продуктивності датчика для виявлення корозії планера в реальних умовах [13].

Цікавим може стати використання рентгенівських методів для виявлення корозії в конструкції літаків [14].

Промисловий метод рентгенографічного тестування та цифрова рентгенографія - два найважливіші інструменти для виявлення різних видів дефектів алюмінієвих конструкцій. Однак через більшу чутливість і динамічний діапазон фоссрорних пластин рентгенографрія може виробляти чіткі і висококонтрастні зображення, але зображення цифрової рентгенографії здаються туманними. У даному дослідженні розроблений алгоритм розбиття цифрових рентгенографрічних зображень деталей літака для видалення туману. Результати показують, що зображення з видаленим туманом мають кращу контрастність, а фрорми дефектів дуже чіткі. Крім того, деякі невидимі тріщини в цифрових зображеннях можна побачити на зображенні, що знімається (рис. 17).
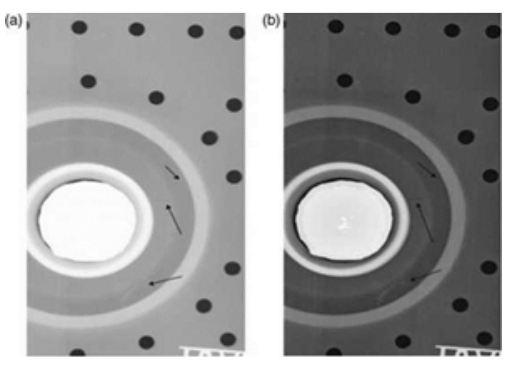

Рис. 17. Рентгенографічне зображення частини структури літака:

(a) - головне зображення при наявності туману; (b) - зображення 3 видаленим туманом. Деякі дефекти виявляються тільки після видалення туману 
Маючи різноманітні датчики вважається за доцільне об'єднати їх в одну мережу в масштабах літака і проводити комплексне обстеження технічного стану конструкції на основі комп'ютерної обробки результатів, отриманих 3 наявних датчиків та обладнання.

\section{Список літератури (Reference)}

1. Електронний $\quad$ ресурc. URL: http://www.corrosiondoctors.org/Aircraft/Aircraft.htm

2. J.F. Wildey II, "Aging Aircraft", Materials Performance, March 1990, pp.80-85.

3. Електронний ресурс.

URL: https://sfw.so/1149033220-aloha-airlines-243-neveroyatnaya-posadkapovrezhdennogo-samoleta.html

4. Електронний ресурс. URL: http://www.corrosion-doctors.org/Formscrevice/pillowing2.htm

5. Aircraft Accident Report-Aloha Airlines, Flight 243, Boeing 737-200, N73711, near Maui, Hawaii, April 28,1988. Report Date: June 14,1989/National Transportation Safety Board Bureau of Accident investigation, Washington, D.C. 20594 - 262 pages

6. Електронний ресурc. URL: http://www.corrosion-doctors.org/Formscrevice/pillowing1.htm

7. Електронний ресурc. URL: https://en.wikipedia.org/wiki/Lockheed_CP140_Aurora

8. Електронний ресурc. URL: http://www.corrosion-doctors.org/Formscrevice/rivets.htm

9. Електронний ресурс. URL: http://www.corrosion-doctors.org/Formscrevice/rivets2.htm

10. Електронний ресурc. URL: https://www.aviationpros.com/home/article/103 81745/spotting-treating-and-preventing-corrosion

11. Sensors and Actuators B: Chemical Journal. Homepage www.elsevier.com/locate/snb. Liquid detection in confined aircraft structures based on lyotropic percolation thresholds/Helge Pfeiffera'*, Peter Heerb, Ioannis Pitropakisa, Gregory Pykaa, Greet Kerckhofsa, Maria Patitsaa, Martine Weversa Katholieke Universiteit Leuven, Department of Metallurgy and Materials Engineering (MTM)

12. Hindawi Publishing Corporation International Journal of Aerospace Engineering Volume 2012, Article ID 684024, 11 pages doi:10.1155/2012/684024

Research Articl: Corrosion Sensor Development for Condition-Based Maintenance of Aircraft / Gino Rinaldi,1 Trisha Huber,2 Heather Mclntosh,3 Les Lebrun,3 Heping Ding,3 and John Weber3. NRC Institute for Aerospace Research, National Research Council Canada, Institute for Microstructural Sciences, National Research Council Canada

13. Contents lists available at SciVerse ScienceDirect._Sensors and Actuators B: Chemical journal homepage www.elsevier.com/locate/snb. Optical sensors for corrosion detection in airframes/P.G. Venancio ${ }^{a}{ }^{b}{ }^{c}$, R.A. Cottis ${ }^{d}$, R. Narayanaswamy ${ }^{e}$, J.C.S. Fernandes ${ }^{b} c * a$ OGMA, Industrie Aeronautica de Portugal, 2615-173 Alverca, Portugal ${ }^{b}$ Department of Chemical Engineering, Instituto Superior Tecnico, TULisbon, 1049-001 Lisboa, Portugal ${ }^{c}$ ICEMS, Instituto Superior Tecnico, 1049-001 Lisbon, Portugal ${ }^{d}$ Corrosion and Protection Centre, The University of Manchester, Manchester M13 9PL, United Kingdom ${ }^{e}$ Centre for Instrumentation and Analytical Science, University of Manchester, Manchester M60 
1QD, United Kingdom. Article history: Received 23 July 2012. Available online 22 March 2013

14. Nondestructive Testing and Evaluation, 2015. Enhanced radiographic imaging of defects in aircraft structure materials with the dehazing method/Effat Yahaghi $^{\mathrm{a} *}$, Amir Movafeghi ${ }^{\mathrm{b}}$, Nooreddin Mohmmadzadeh ${ }^{\mathrm{b}-\mathrm{a}}$ Department of Physics, Imam Khomeini International University, Ghazvin, Iran; ${ }^{b}$ Nuclear Safety and Radiological Protection Department, Nuclear Science and Technology Research Institute, Tehran, Iran.

Надійшла до редакції 11.03.2019, розглянута на редколегії 15.03.2019.

\section{Повреждения от щелевой коррозии в конструкциях самолетов и их обнаружение}

Представлены примеры разрушения конструкций самолетов в результате коррозии металлов в условиях усталостного нагружения. Показано, что щелевая коррозия, которая представляет собой усиление коррозии в щелях и зазорах между двумя металлами, а также в местах неплотного контакта металла с неметаллическим корозионноинертним материалом приводит, в соединениях обшивок с подкрепляющим силовым набором, к появления продуктов коррозии, которые могут привести к вспучиванию одних элементов соединения относительно других элементов и провоцировать отрыв закладных головок заклепок с последующим развитием усталостных трещин и разрушением конструкций самолета.

Показано, что визуальный осмотр не всегда эфффективен для выявления коррозионных повреждений, а иногда невозможен, например в замкнутых внутренних объемах конструкций.

Приведены новые разработки в области датчиков и оборудования для обнаружения коррозионно активных веществ и коррозионных повреждений. Среди них предоставлена информация о датчике (органико-керамический композит), содержащем проводящий комплекс. Когда композит подвергают воздействию водных жидкостей, его проводимость теряется. Когда композит высохнет, датчик достигает своих первоначальных значений сопротивления.

Приведена информация об оптическом датчике для обнаружения коррозии в планерах. Этот датчик основан на дистанционном обнаружении ионов алюминия, образующихся в процессе коррозии.

Представленная разработка многопараметрического интегрированного датчика для оценки структурной целостности алюминиевых сплавов, регистрирующего концентрацию хлорид-ионов, выделение водорода, изменение влажности и деградацию материала.

Приведена информация об оптических датчики, основанных на излучении фрлуоресценции, которые используют для выявления специфических ионов, таких как алюминий, указывающих на начало коррозии алюминиевого сплава.

Предоставлена информация о разработке улучшенных цифровых рентгеновских методов для выявления коррозии в конструкции самолетов.

Сделан вывод о необходимости сочетания визуального контроля и контроля с использованием средств и методов выявления коррозионно активных веществ и коррозионных повреждений. 
Ключевые слова: коррозия металлов, щелевая коррозия, коррозионноусталостные повреждения, методы выявления коррозии, датчик коррозии

\section{Damage from crevice corrosion in aircraft designs and their detection}

Presented examples of destruction of aircraft designs due to corrosion of metals under conditions of fatigue loading. It is shown that slit corrosion, which is an increase in corrosion in crevice and gaps between two metals, as well as in places of untight contact of metal with a nonmetallic material resistant to corrosion, leads to the appearance of corrosion products in the joints of the skin with the power suite, which supports it, which can lead to the swelling of some elements of the joint relative to other elements and provoke the tearing off of the heads of rivets with the further development of fatigue cracks and the destruction of aircraft structures.

Shown, that visual inspection is not always effective for the detection of corrosion damage, and sometimes impossible, for example, in closed internal structures.

New developments in the field of sensors and equipment for the detection of corrosive substances and corrosion damage are presented. Among them is information on the sensor (organic-ceramic composite) containing the conducting complex. When the composite is exposed to water liquids, its conductivity is lost. When the composite dries, the sensor reaches its initial values of resistance.

Information is provided on the optical sensor for detecting corrosion in the construction of the airframe. This sensor is based on the remote detection of aluminum ions formed during corrosion.

The development of a multi-parameter integrated sensor for assessing the structural integrity of aluminum alloys, the recording of the concentration of chloride ions, the release of hydrogen, changes in humidity and degradation of the material is presented.

Information is provided on fluorescence-based optical sensors used to detect specific ions such as aluminum, indicating the beginning of corrosion of an aluminum alloy.

Information is provided on the development of advanced digital X-ray methods for the detection of corrosion in the design of aircraft.

The conclusion is made on the necessity of combining visual control and control with the use of means and methods for detecting corrosive substances and corrosion damage.

Keywords: metal corrosion, crevice corrosion, corrosion fatigue damage, corrosion detection methods, corrosion sensor

\section{Відомості про авторів}

Топал Микола Савович - доцент кафедри проектування літаків та вертольотів Національного аерокосмічного університету ім. М. Є. Жуковського «XAI», Україна, ORCID: 0000-0002-4901-8653.

Андрющенко Володимир Михайлович - старший науковий співробітник, кандидат технічних наук, доцент кафедри проектування літаків та вертольотів Національного аерокосмічного університету ім. М. Є. Жуковського «XAI», Україна, ORCID: 0000-0003-1013-3803. 